\title{
AGE CHARACTERISTICS OF MORPHOGENESIS OF DIABETIC MYOPATHIES*
}

\author{
Zhurakivska O. Ya., Koshkin O. Ye., Tkachuk Y. L., \\ Rudyak O. M., Knyazevych-Chorna T. V. \\ Ivano-Frankivsk National Medical University, Ministry of Health of Ukraine, \\ Ivano-Frankivsk, Ukraine \\ Izhurakivska.o.ya@gmail.com
}

Diabetes mellitus (DM) is the most acute medical and social problem of the national health care system all over the world and it is associated with the constant growth of the disease, severe complications and high mortality, especially among the working population $[1,2]$. Skeletal muscle is known to be one of the major tissues that determines carbohydrate metabolism in the body, as it is the main target for insulin action in regulation of blood glucose levels by activating insulin-sensitive glucose transporter-4 (GLUT-4) on the plasma cell membrane [3]. In diabetes, glucose uptake by skeletal muscle decreases due to impaired glycogen synthesis and it leads to impaired metabolic changes in skeletal muscles and the body as a whole [3].

One of the DM complications is diabetic myopathy, which occurs in $88 \%$ of patients [4] and is often combined with other complications of diabetes, such as macro- and microangiopathy, cardiovascular disease, nephropathy, retinopathy, neuropathy [2].

In the scientific literature there are works, describing morphofunctional changes of neuromuscular connections (NMC) in experimental diabetes in the masticatory muscle and tongue of mature rats [5, 6]. However, we have not found investigations, that have comprehensively studied the structural changes in the masticatory muscles in diabetes in the postnatal period of ontogenesis.

In view of the above, the purpose of our study was to establish the age characteristics of histo-ultrastructural changes in the masticatory muscle of 2-month (immature) and 6-month (mature) rats with streptozotocin-induced diabetes mellitus (SDM).

* In this article the material of the dissertation research, which is performed according to the plan of IvanoFrankivsk National Medical University and is a part of the research work of the Department of Human Anatomy «Age features of pathomorphogenesis of some organs of neuroendocrine, cardiovascular, digestive and respiratory systems in diabetes» (№ of state registration 0116U003598) was used.

Institution, which financed the research: Ministry of Health of Ukraine

The authors assume responsibility for the published work.

The authors guarantee absence of competing interests and their own financial interest when carrying out the research and writing the article.

The manuscript was received by the editorial staff 15.12.2020. 


\section{MATERIALS AND METHODS}

The material for the study were the masticatory muscles of 10 immature (weighing $65-95 \mathrm{~g}$ ) and 10 mature (weighing 160-180 g) white outbred male rats, which were divided into 2 groups: control (10 animals) and experimental (10 animals). SDM in the experimental group was simulated by a single intraperitoneal injection of streptozotocin (dissolved in $0.1 \mathrm{M}$ citrate buffer solution with a $\mathrm{pH}$ of 4.5) at a dose of $7 \mathrm{mg}$ per $100 \mathrm{~g}$ body weight in immature animals and $6 \mathrm{mg}$ per $100 \mathrm{~g}$ body weight in adult animals. In the control group of animals, the equal volume of citrate buffer was injected intraperitoneally. In order to avoid hypoglycemia (because of the destruction of B-cells), rats received additional glucose dose for one day. The level of glucose in the experimental group of animals was measured daily from the tail vein blood using glucose meter test strip "Accu-Chec" (Germany). The material was taken on the $70^{\text {th }}$ day of the experiment. Histological (hematoxylin and eosin staining, Masson's trichrome), histochemical (Shabadash glycogen detection, Bolshevsky-Gross impregnation), biochemical and electron microscopic methods were used.
All manipulations performed on animals during the experiment did not contradict the European Convention for the Protection of Vertebrate Animals Used for Research and Other Scientific Purposes (Strasbourg, 1986), Council of Europe Directive 86/609 / EEC (1986), Law of Ukraine "Protection of animals from cruel treatment» of December 15, 2009 and orders of the Ministry of Health of Ukraine № 690 of September 23, 2009, № 616 of August 3, 2012.

For morphometric studies, photographs of histological sections saved in tif format were used. Morphometry was performed using ImageJ version $1.47 \mathrm{t}$. We have determined the cross-sectional area of muscle fibers (MF) and their nuclei, and the area of neuromuscular junctions (NMJs). The area of the profile of arterioles, capillaries, venules, their walls and lumen was measured. In arterioles and capillaries, the Vogenvort index (iV) was determined according to the formula [7]. Computer data processing was performed using the statistical package STATISTICA (StatSoft, Inc. (2010), STATISTICA (data analysis software system), version 10.

\section{RESULTS AND THEIR DISCUSSION}

On the $70^{\text {th }}$ day of SDM, the level of glucose and glycosylated hemoglobin in adult animals increased to $20.12 \pm 2.34 \mathrm{mmol} / \mathrm{l}$ (control $4.56 \pm 0.83 \mathrm{mmol} / \mathrm{l}, \mathrm{p}=0.0001)$ and $11.21 \pm$ $1.36 \%$ (control $-2.46 \pm 0.59 \%, p=0.0001$ ), while in immature rats these figures were significantly lower: $15.32 \pm 1.53 \mathrm{mmol} / \mathrm{l}$ (control $3.76 \pm 0.25 \mathrm{mmol} / \mathrm{l}, \mathrm{p}=0.0001)$ and $9.58 \pm$ $0.73 \%$ (control $-2.29 \pm 0.35 \%, p=0.0012$ ), respectively (in all cases, $p<0.05$ ).

In adult rats, the area of MF and their nuclei is likely to decrease to $433.53 \pm 54.11{\mu m^{2}}^{2}$

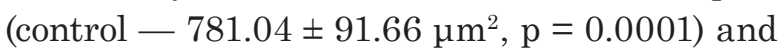

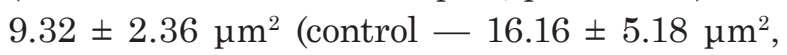
$p=0.0001$ ), while in immature rats the area of MF decreases to $431.02 \pm 49.33 \mathrm{\mu m}^{2}$ (control $558.93 \pm 35.96 \mu^{2}, p=0.0001$ ), while the area of the nuclei probably does not differ from the control values of $16.07 \pm 4.82{\mu \mathrm{m}^{2}}^{\text {(control - }}$

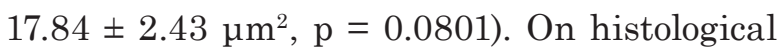
specimens of adult animals, edema of endo- and perimysium is observed. Glycogen granules in MF may be absent or appear in the form of small clusters on the periphery (Fig. 1a). In contrast, in immature rats, perimysium edema is detected only perivascular, and glycogen inclusions vary from insignificant to pronounced in different MF (Fig. 1e). In immature animals, muscle sequestration and sometimes aseptic inflammatory cellular infiltrates are observed (Fig. 1f), while in adult animals, fibrosis and focal lysis of individual MF, sometimes their necrosis and partial replacement by connective tissue are detected (Fig. 1 b).

At the ultrastructural level in the masticatory muscle of adult rats, partial necrosis of MF, karyorexis, subsarcolemic edema, separation of fibers and lysis of myofibrils, destruction of mitochondrial cristae are detected (Fig. 2 a). There is an increasing number of macrophages and fibroblasts in these areas. The latter produce collagen, which fills the endo- and perimysium, sometimes replacing the destroyed MF by foci of sclerosis. Along with destructively 

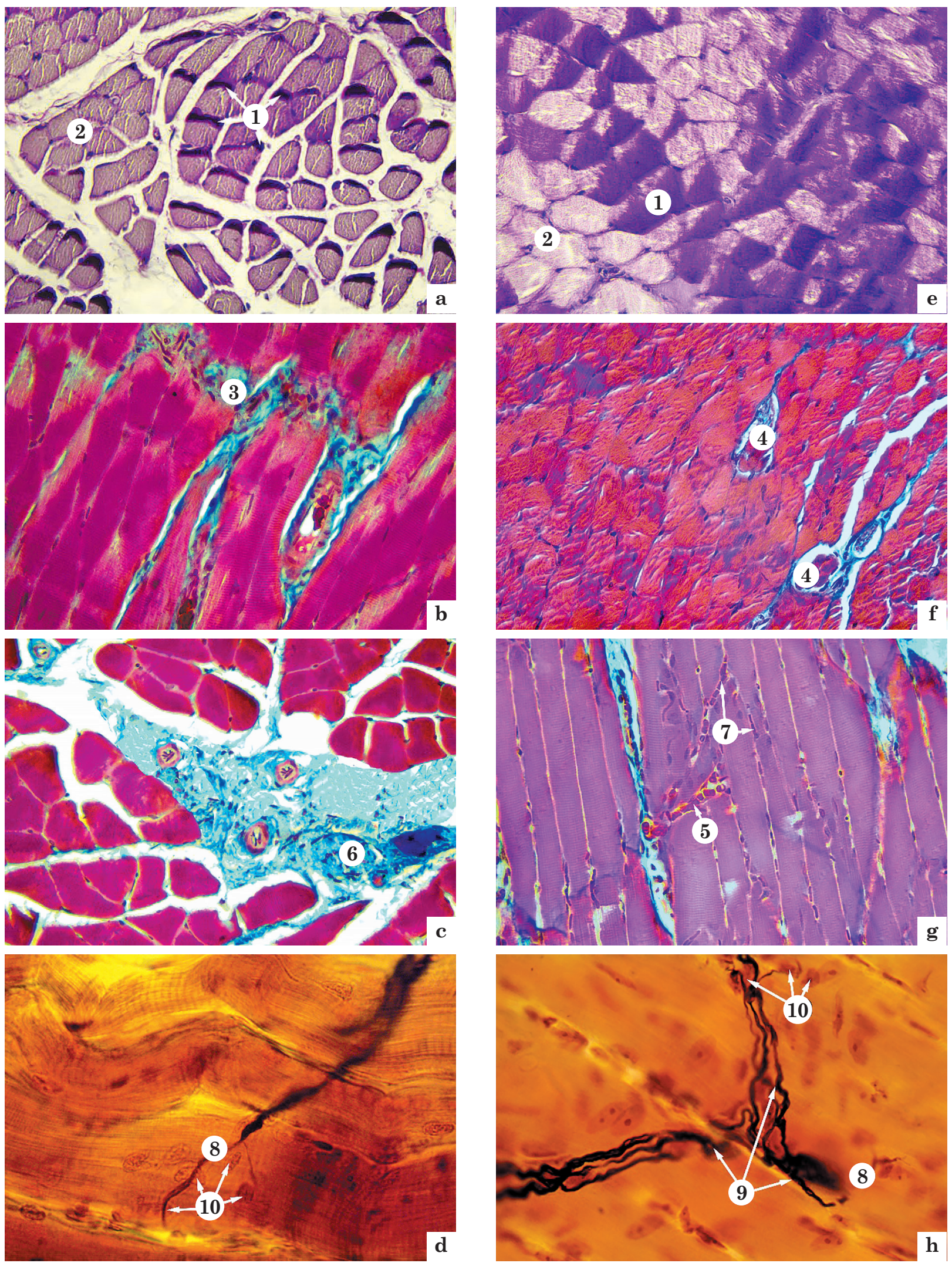

Fig. 1. Histostructural changes in the masticatory muscle of mature (a-d) and immature (e-h) rats with SDM. Staining: according to Shabadash (a, e), Masson's trichrome (b, c, f, g), impregnation according to Bilshovsky-Gross (d, h). Microphotographs. Enlarged: a, b, c, e, f; g) 400; d, h) 1000. Symbols: 1 - inclusion of glycogen in MF, 2 - MF without glycogen, 3 - sclerosis of MF; 4 - MF sequestration, 5 - arteriolovenular anastomosis, 6 - aseptic inflammatory cell infiltrates, 7 - erythrocyte sludges, 8 - terminal branches of the axon, 9 - nerve collaterals, 10 - nuclei of terminal neurolemmocytes. 

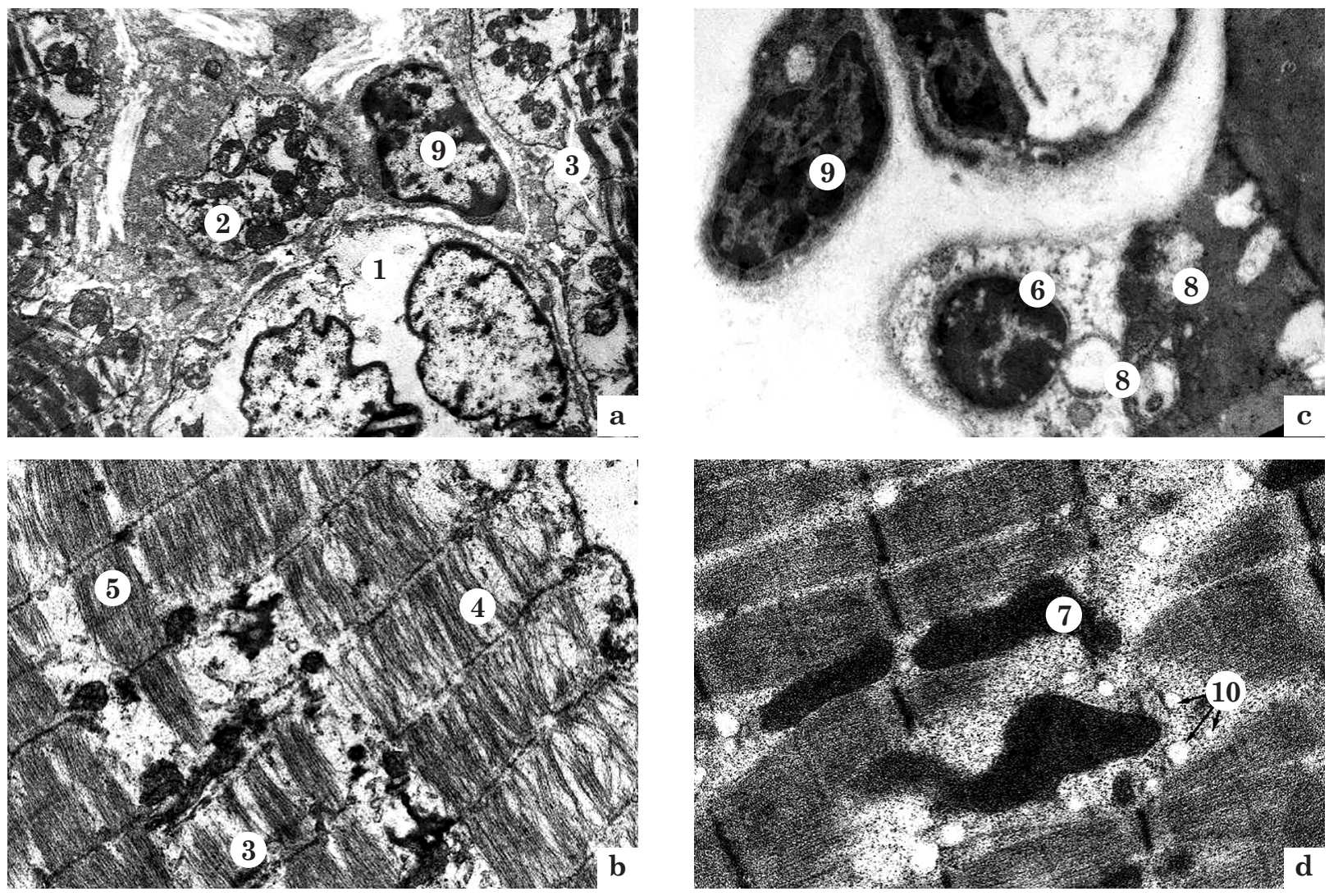

Fig. 2. Partial necrosis (a) and focal lysis of myofibrils (b) in MF of adult rats and apoptosis (c) and intracellular regeneration processes (d) in MF of immature rats on the $70^{\text {th }}$ day of SDM. Electronic microphotographs. Enlarged: a) 4800, b) 9600, c) 8000, d) 16000.

Symbols: 1 - partial necrosis, 2 - myosateliocyte, 3 - lysis of myofibrils, 4 - separation of myofibrils, 5 - normal myofibrils, 6 - apoptosis, 7 - young mitochondria, 8 - destructively altered mitochondria, 9 - fibroblast nucleus, 10 - terminal cistern of sarcoplasmic reticulum.

changed MF, MFs with preserved structural components are visualized (Fig. 2 b). In contrast to adult animals, karyopyknosis, apoptosis, and vacuolar dystrophy of MF are observed in 2-month-old SDM rats (Fig. 2 c). Other MFs are characterized by the following intracellular regenerative processes: formation of young mitochondria with a dense matrix and indistinctly differentiated crystals; the appearance of numerous granules of glycogen in the sarcoplasm between myofibrils, a slight expansion of structural components of the sarcoplasmic reticulum (Fig. 2 d).

Such changes in the masticatory muscle of MF are caused by several factors. First, hyperglycemia promotes glycosylation of proteins (actin and myosin), which in turn are chemically modified [8] and lead to other complications associated with type 1 diabetes [9]. Some researchers found an increased content of glycosylation end products in proteins of skeletal muscle which led to a decrease in the mobility of actin and myosin, causing a glucose-dependent decrease in myofibril function [10].

There is a narrowing of the lumen of the afferent and metabolic links in the hemomicrocirculatory bed of both age groups of SDM animals, while the lumen of the capacitive link is expanded and the wall area of almost all microvessels increases (Table 1). Such changes lead to the opening of arteriolovenular anastomosis (Fig. 1 g). In adult animals, perivascular edema and connective tissue growth are observed (Fig. 1 c). Histological specimens show congestion of capillaries, venules and veins due to erythrocyte sludges. In the arteries and arterioles, edema is often found, and in some places there is a destruction of the inner elastic membrane which is accompanied by a narrowing of their lumen. iV increases respectively in arterioles and capillaries up to $874.12 \pm 134.49 \%$ (control $-416.43 \pm 68.75 \%$, $\mathrm{p}=0.0001)$ and $369.10 \pm 86.53 \%$ (control $128.03 \pm 24.70 \%, p=0.0001)$ in adult animals 
Morphometric changes of the hemomicrocirculatory on the $\mathbf{7 0}^{\text {th }}$ day of the development of experimental diabetes mellitus, $n=10\left(X \pm S_{X}\right)$

\begin{tabular}{|c|c|c|c|c|}
\hline $\begin{array}{c}\text { Vessels of } \\
\text { HMCS }\end{array}$ & $\begin{array}{l}\text { Group of } \\
\text { animals }\end{array}$ & $\begin{array}{c}\text { Area of the vessel } \\
\left(\mu^{2}\right)\end{array}$ & $\begin{array}{c}\text { Area of the lumen } \\
\left(\mu^{2}\right)\end{array}$ & $\begin{array}{c}\text { Area of the } \\
\text { wall }\left(\mu^{2}\right)\end{array}$ \\
\hline \multicolumn{5}{|c|}{ Immature animals } \\
\hline \multirow{2}{*}{ Arterioles } & SDM & $305.20 \pm 15.78$ & $40.73 \pm 7.12^{*}$ & $264.47 \pm 16.89^{*}$ \\
\hline & control & $301.06 \pm 16.56$ & $75.30 \pm 9.20$ & $225.75 \pm 14.04$ \\
\hline \multirow{2}{*}{ Capillaries } & SDM & $16.55 \pm 2.64$ & $4.75 \pm 0.79 *$ & $11.80 \pm 2.26^{*}$ \\
\hline & control & $16.32 \pm 1.94$ & $6.98 \pm 1.24$ & $9.34 \pm 0.99$ \\
\hline \multirow{2}{*}{ Venules } & SDM & $305.44 \pm 27.45$ & $169.70 \pm 23.33^{*}$ & $135.75 \pm 32.07$ \\
\hline & control & $304.25 \pm 333.03$ & $141.27 \pm 20.13$ & $162.97 \pm 26.01$ \\
\hline \multicolumn{5}{|c|}{ Mature animals } \\
\hline \multirow{2}{*}{ Arterioles } & SDM & $341.82 \pm 51.37^{*}$ & $35.09 \pm 7.26^{*}$ & $306.73 \pm 41.24^{*}$ \\
\hline & control & $326.13 \pm 40.12$ & $63.15 \pm 8.36$ & $262.98 \pm 34,71$ \\
\hline \multirow{2}{*}{ Capillaries } & SDM & $25.05 \pm 5.12^{*}$ & $5.34 \pm 0.92 *$ & $19.71 \pm 3.52^{*}$ \\
\hline & control & $19.36 \pm 2.54$ & $8.49 \pm 1.27$ & $10.87 \pm 2.23$ \\
\hline \multirow{2}{*}{ Venules } & SDM & $418.26 \pm 59.61^{*}$ & $169.72 \pm 25.96 *$ & $248.54 \pm 33.73^{*}$ \\
\hline & control & $372.89 \pm 54.72$ & $149.98 \pm 31.02$ & $222.91 \pm 35.28$ \\
\hline
\end{tabular}

Note:

* probable difference with control within one age group of animals $(p<0.05)$.

up to $669.43 \pm 42.32 \%$ (control $-304.06 \pm$ $44.84 \%, \mathrm{p}=0.0001$ ) and $252.67 \pm 51.42 \%$ (control $-136.66 \pm 22.89 \%, p=0.0001)$ which indicates a significant decrease in the capacity of the afferent and exchange links of the hemomicrocirculatory bed. The bloodstream of the masticatory muscle of animals of different age groups with SDM becomes thin, which indicates a decrease in the number of hemocapillaries per $0.1 \mathrm{~mm}^{2}$ of masticatory muscle in adult rats up to $41.3 \pm 8.42$ (control $-83.6 \pm$ $6.29, \mathrm{p}=0.0001)$, in immature rats - up to $70.9 \pm 4.02$ (control $-87.5 \pm 4.01, \mathrm{p}=0.0002)$.

At the ultrastructural level, in the lumen of vessels of the hemomicrocirculatory bed, the erythrocyte sludges, adhesion of erythrocytes and platelets to the lumenal surface of endothelial cells and microthrombi are observed. Hemorheological disorders of the blood are associated with hyperglycemia, high levels of glycated hemoglobin and diproteinemia, which increase blood viscosity and lead to changes in the surface charge of erythrocytes with adhesion of fibrinogen and B-lipoproteins to their surface [11, 12]. Increased platelet aggregation capacity occurs due to violations of their functional state which are caused by damage to cellular structures under the influence of peroxynitrite [12]. In addition, there is glycosylation of protein elements of the anticoagulant system of the blood, and it is an additional factor in local thrombosis [13]. In most endothelial cells of microvessels, the karyopyknosis and increase in electronic density of cytoplasm are observed; the lumenal surface of a plasmolemma forms protrusions with the subsequent expressed microclasmatosis. In the lumen of some vessels of mature animals, macroclasmatosis is observed due to partial desquamation of peripheral parts. Other endotheliocytes retain their ultrastructural organization, but their peripheral divisions are significantly thickened. The destruction of endothelial cells in diabetes is described by other authors $[11,13]$; they relate this to a number of factors. First, in diabetes, the level of contrainsular hormones is increased [1], they activate the polyol pathway of glucose metabolism, which leads to osmotic edema and destruction of endothelial cells [13]. Second, hyperglycemia and high levels of glucocorticoids lead to the breakdown of proteins with the formation of antigens and the development of an autoimmune process in the vascular endothelium. As a result, autoimmune 
complexes depolymerize the main substance of vascular walls and lead to the development of hyalinosis and their thickening [14]. The leading role belongs to the processes of lipid peroxidation, which leads to the formation of free radicals that damage the endothelium [13, 14]. As a result, endothelial cells do not fully synthesize biologically active substances that affect vascular tone. According to our studies, in 6-month-old rats, the proliferation of the basement membrane in the form of individual plates is observed, which is one of the characteristic features of diabetic microangiopathy. According to the literature, there are three pathogenetic mechanisms which are the basis of damage of the basement membrane: metabolic (enzymatic and non-enzymatic glycosylation of its proteins), hypoxic and immunocomplex (disruption of relationships between proteoglycans and other components of the basement membrane) $[11,13]$. We also noted damage to pericytes, in the cytoplasm of which small and large vacuoles, dilated cisterns of the granular endoplasmic reticulum and partially destroyed mitochondria were found. At the same time the number of polysomes and free ribosomes decreases. In some hemocapillaries the destruction of their wall is observed. Around the capillaries there is a noticeable swelling and growth of collagen fibers and connective tissue stroma.

In immature animals, changes in the hemomicrocirculatory bed were less pronounced (Fig. 2 c). Erythrocyte sludges and microclasmatosis were observed in the lumen of some capillaries. Most endothelial cells were electron-dense with numerous micropinocytic vesicles. Such dark endotheliocytes are attributed by most authors to young cells [15], which may indicate the regenerative processes of the inner lining of micro-hemo-vessels, which are triggered in response to endothelial cell damage. In the regeneration of endothelial cells, the leading role is played by endothelial growth factor, fibroblast and platelet growth factor, angiopoietins and others, which activate the following processes of endothelial cell regeneration: migration, proliferation and remodeling [13].

On the $70^{\text {th }}$ day of the SDM, there is a massive destruction of NMJs in adult rats, which leads to a decrease in their area up to
$129.84 \pm 25.27 \mu^{2}$ (control $-395.72 \pm 21.18 \mu^{2}$, $\mathrm{p}=0.0001)$. It is accompanied by homogenization and varicose thickenings of the myelin sheath and axonal atrophy (Fig. 1d). At the ultrastructural level, the axoplasm is clarified in neuromuscular synapses, it has no neurofilaments and other specific inclusions; there is a small number of synaptic vesicles, and mitochondria have a clarified matrix and destroyed cristae. Most of the postsynaptic folds are destroyed exposing the postsynaptic membrane. The postsynaptic folds are destroyed and as a result the presynaptic pole of neuromuscular synapses ceases to exist (Fig. 3 a). Remains of axoplasm are observed in these areas. Such degenerative changes indicate a significant disturbance in the axonal transport system and are observed in many pathological conditions when it comes to hypoxia, and they are caused primarily by changes in blood microcirculation $[9,15]$, and in our case - by the development of diabetic microangiopathy. According to some authors [16], in diabetes the function of the synaptic apparatus of skeletal muscles is impaired due to the appearance of autoantibodies to $\mathrm{Ca}^{2+}$-channel receptors on the presynaptic membrane of the NMJs. Other authors [17] believe that in diabetes there is a glycosylation of proteins in muscle fibers due to increased expression of genes that control the ubiquitindependent proteolytic system, and as a consequence, lead to changes in acetylcholine receptors, which was confirmed by our study at the ultrastructural level.

In 2-month-old rats with SDM, there was also a decrease in the branching area of the axon terminal up to $182.40 \pm 33.91 \mu^{2}$ (cont$\left.\mathrm{rol}-454.86 \pm 37.51 \mathrm{\mu m}^{2}, \mathrm{p}=0.0001\right)$. However, in some NMJs, the reinnervation processes are observed due to collaterals from neighboring nerve fibers (Fig. 1 h). Nerve sprouting in diabetes has been observed by other researchers $[17,18]$ and it is interpreted as compensatory-adaptive processes of axons in various pathological processes to certain abnormal conditions or inactivity of muscle fibers. Besides, they believe that terminal neurolemmocytes in the area of damaged NMJs stimulate the production of insulin-like growth factor-1, thus initiating an increase in the number of axon terminal branches, which was studied in our 

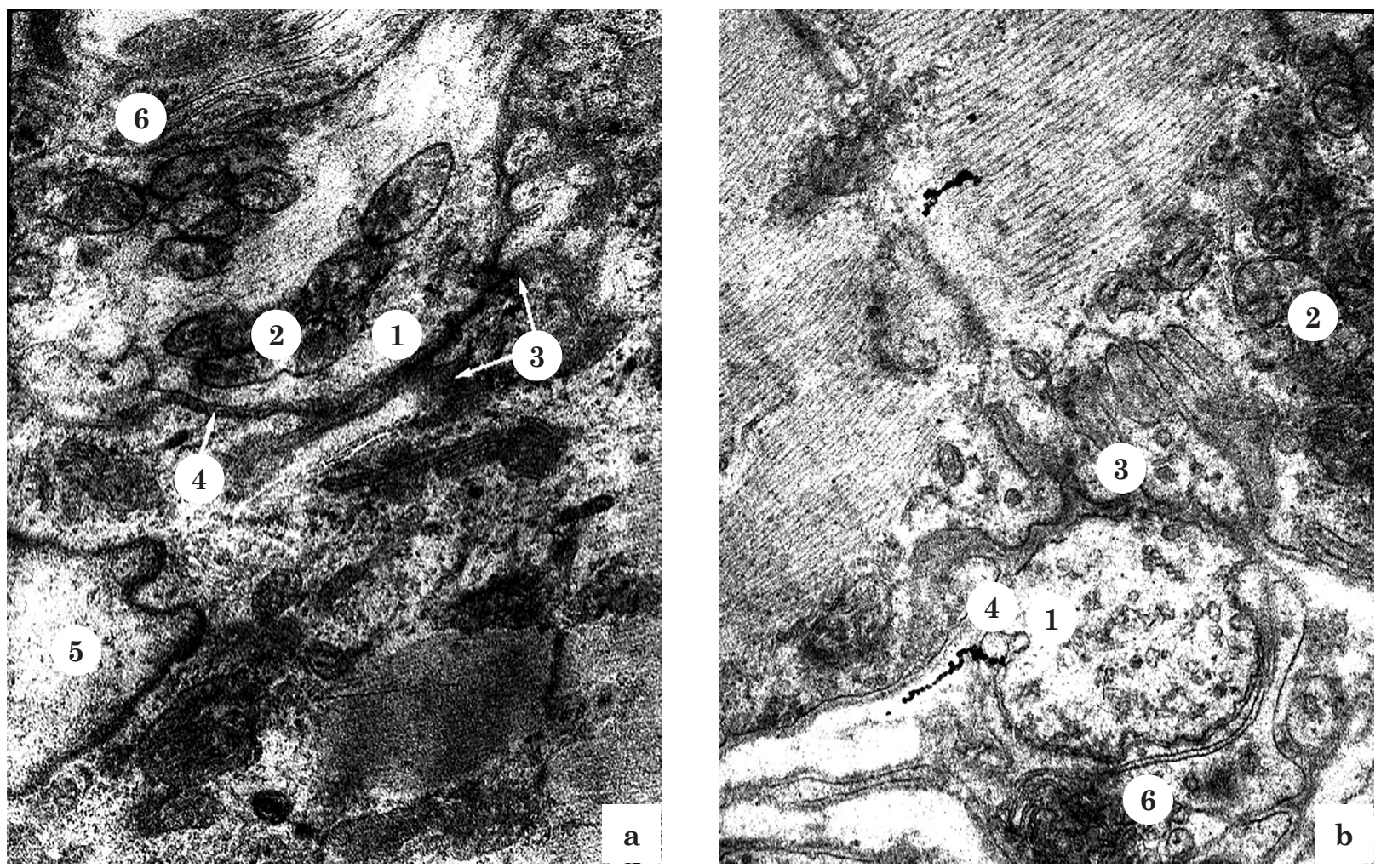

Fig. 3. Ultrastructural changes in the neuromuscular synapse of the masticatory muscle of mature (a)

and immature (b) rats on the $70^{\text {th }}$ day of SDM. Electronic microphotographs. Enlarged: a) 12000 , b) 16000.

Symbols: 1 - axoplasm with synaptic vesicles, 2 - mitochondria, 3 - synaptic folds, 4 - synaptic cleft, 5 - MF nucleus, 6 - processes of the final neurolemmocyte.

research. Thus, in immature rats, the area of NMJs, compared with control indicators, decreases by only $54 \%$, and in mature rats - by $67 \%$, which indicates the presence of compensatory-restorative processes in NMJs of im- mature rats. At the ultrastructural level, in neuromuscular synapses there is a partial destruction of the synaptic folds and an increase in the distance between them and the width of the synaptic cleft (Fig. 3 b).

\section{CONCLUSIONS}

Thus, taking into account the data of histological, morphometric and electron-microscopic studies, we can conclude that there is a diabetic myopathy on the $70^{\text {th }}$ day of the SDM in the masticatory muscle of rats of different ages. The main pathomorphological mechanisms of its occurrence are hypoxia due to the develop- ment of diabetic microangiopathy and peripheral neuropathy. At the same time, in adult animals it leads to atrophy and partial sclerosis of the MF of masticatory muscle; and in immature animals, compensatory-restorative processes in the NMJs and MF are revealed.

\section{REFERENCES}

1. Tkachuk YL. Journal of Education, Health and Sport formerly Journal of Health Sciences 2016; 6(4): 375-384.

2. Zhurakivska OY, Mykulets TI, Dutchak UM, et al. World of medicine and biology 2018; 1: 126-130. doi: 10.26.724/2079-8334-2018-1-63-126-130.

3. Venojärvi M, Puhke R, Hämäläinen H, et al. Diabetes, Obesity and Metabolism 2005; 7: 745-754.
4. Krause MP, Riddell MC, Hawke TJ. Pediatr Diabetes 2011; 12(4 Pt 1): 345-364. doi: 10.1111/j.1399-5448.2010.00699.x.

5. Zhurakivska OYa, Grad AO, Popel SL, et al. World of medicine and biology 2017;3(61): 108-114. doi: 10.26724 / 2079-8334-2017-3-61-108-114.

6. Levitskiy VA, Atamanchuk OV. Journal of the Grodno State Medical University 2014;46: 70-74. 
7. Slavnov AA, Dolgikh VT. General Reanimatology 2014; 10(4): 37-43. doi: 10.15360/1813-9779.2014.10.4.37-43.

8. Zishan Md. J Pharm Pharm Sci 2017; 7: 448-470, available at: https://doi.org/10.20959/wjpps20175-9135.

9. Stepanova Z, Maksyukov S, Skorobogach M, et al. Medical news of the North Caucasus 2017; 12(20): 34-42, available at: https://doi.org/10.14300/mnnc.2017.12051.

10. Reddy VS, Jakhotia S, Reddy PY, Reddy GB. IUBMB Life 2015; 67(4): 291-299.

11. Kuryliszyn-Moskal A, Zarzycki W, Dubicki A, et al. Adv Med Sci 2017; 62(2): 368-373.

12. Madonna R, Balistreri CR, Geng YJ, De Caterina R. Vascul Pharmacol 2017; 90: 1-7. doi: 10.1016/j.vph.2017. 01.004 .
13. Yushkov PV, Opalenov KV. Diabetes mellitus 2001; 4(1): 53-56.

14. Leung WK, Gao L, Siu PM, Lai CW. Life Sci 2016; 166: 121-130. doi: 10.1016/j.lfs.2016.10.015.

15. Tokaruk NS. Topical problems of modern medicine: Bull. of the Ukr. Med. Dent. Acad 2016; 16(1): 249-255.

16. Garcia CC, Potian JG, Hognason K, et al. Am J Physiol Endocrinol Metab 2012; 303: 551-561. doi:10.1152/ajpendo.00622.2011.

17. Marques MJ, Neto HS. The Anat Record 2002; 267: 112119.

18. Fahim MA, Hasan MY, Alshuaib WB. J Appl Physiol 2000; 89: 2235-2240. doi.org/10.1152/jappl.2000.89.6.2235.

\section{ВІКОВІ ОСОБЛИВОСТІ МОРФОГЕНЕЗУ ДІАБЕТИЧНИХ МІОПАТІЙ}

Жураківська О.Я., Кошкін О.Є., Ткачук Ю.Л.,

Князевич-Чорна Т. В., Рудяк О. М.

Івано-Франківський національний медичний університет МОЗ Украйни,

м. Івано-Франківськ, Україна

zhurakivska.o.ya@gmail.com

Одним із ускладнень цукрового діабету (ЦД) е діабетична міопатія, що діагностуеться у $88 \%$ хворих. Тому метою нашої роботи було встановити вікові особливості гісто-ультраструктурних змін жувального м’яза 2-місячних (нестатевозрілих) та 6-місячних (статевозрілих) щурів при стрептозотоциновому цукровому діабеті (СЦД). Останній моделювали одноразовим внутрішньоочеревинним введенням стрептозотоцину в дозі 7 мг на 100 г маси тіла 2-місячним та 6 мг на 100 г маси тіла 6 -місячним щурам.

Встановлено, що на 70-у добу перебігу СЦД в жувальному м’язі 2-місячних щурів відмічаються секвестрація м'яза та вогнищеві асептичні запальні клітинні інфільтрати, тоді як у 6-місячних тварин - розволокнення та вогнищевий лізис окремих м'язових волокон (МВ), подекуди їх некроз та часткове заміщення сполучною тканиною. На ультраструктурному рівні в 6 -міс щурів виявляються явища парціального некрозу МВ, каріорексис, підсарколемальний набряк, розволокнення і лізис міофібрил, руйнування мітохондрій, у 2-міс - наявні внутрішньоклітинні регенераторні процеси: утворення молодих мітохондрій; поява чисельних гранул глікогену в саркоплазмі між міофібрилами. Такі зміни відбуваються на тлі розвитку діабетичної мікроангіопатії. У статевозрілих відмічається масивне руйнування нервово-м'язових з'єднань (НМЗ), що веде до зменшення площі спраутингу аксонів на $67 \%$ і супроводжуеться частковим руйнуванням нейром'язових синапсів. У 2-міс щурів, також, відмічається зменшення площі НМЗ на 54\%, при цьому в окремих НМЗ спостерігаються реііннерваційні процеси внаслідок коллатералей від сусідніх нервових волокон.

Таким чином, у жувальному м'язі щурів різних вікових груп при СЦД діагностується діабетична міопатія, що виникає внаслідок розвитку діабетичної мікроангіопатії та периферійної нейропатії. При цьому у статевозрілих тварин вона призводить до атрофії та часткового склерозу МВ жувального м'яза, а у нестатевозрілих спостерігаються компенсаторно-відновні процеси в НМЗ і МВ.

К л ючов і с лов а: жувальний м'яз, нейром'язове з'єднання, стрептозотоциновий цукровий діабет.

\section{ВОЗРАСТНЫЕ ОСОБЕННОСТИ МОРФОГЕНЕЗА ДИАБЕТИЧЕСКИХ МИОПАТИЙ}

Журакивская О. Я., Кошкин О. Е., Ткачук Ю. Л., Князевич-Чорна Т. В., Рудяк О. М.

Ивано-Франковский национальный медицинский университет МОЗ Украины,

г. Ивано-Франковск, Украина

zhurakivska.o.ya@gmail.com

Одним из осложнений сахарного диабета (СД) является диабетическая миопатия, которая диагностируется у $88 \%$ больных. Поэтому целью нашей работы было установить возрастные особенности гисто- ультраструктурных изменений жевательной мышцы 2-месячных (неполовозрелых) и 6-месячных (половозрелых) крыс при стрептозотоциновом сахарном диабете (ССД). Последний моделировали 
однократным внутрибрюшинным введением стрептозотоцина в дозе 7 мг на 100 г массы тела 2-месячным и 6 мг на 100 г массы тела 6-месячным крысам.

Установлено, что на 70-е сутки течения ССД в жевательной мышце 2-месячных крыс отмечаются секвестрация мышцы и очаговые асептические воспалительные клеточные инфильтраты, тогда как в 6-месячных животных - очаговый лизис отдельных мышечных волокон (МВ), иногда их некроз и частичное замещение соединительной тканью. На ультраструктурном уровне у 6-месячных крыс обнаруживаются явления парциального некроза МВ, кариорексис, подсарколемальний отек, разрыхление и лизис миофибрилл, разрушения митохондрий, у 2-месячных - наблюдаются внутриклеточные регенераторные процессы: образование молодых митохондрий; появление многочисленных гранул гликогена в саркоплазме между миофибриллами. Такие изменения происходят на фоне развития диабетической микроангиопатии. У половозрелых крыс отмечается массивное разрушение нервномышечных соединений (HМC), что ведет к уменьшению площади спраутинга аксонов на $67 \%$ и сопровождается частичным разрушением нейромышечных синапсов. У 2-месячных крыс также отмечается уменьшение площади НМС на $54 \%$, при этом в отдельных НМС наблюдаются реиннервационные процессы вследствие коллатералей от соседних нервных волокон.

Таким образом, в жевательной мышце крыс разных возрастных групп при ССД диагностируется диабетическая миопатия, возникающая вследствие развития диабетической микроангиопатии и периферической нейропатии. При этом у половозрелых животных она приводит к атрофии и частичному склерозу МВ жевательной мышцы, а у неполовозрелых наблюдаются компенсаторно-восстановительные процессы в НМС и МВ.

К л ючевые слова: жевательная мышца, нейромышечное соединения, стрептозотоциновый сахарный диабет.

\section{AGE CHARACTERISTICS OF MORPHOGENESIS OF DIABETIC MYOPATHIES}

Zhurakivska O. Ya., Koshkin O. Ye., Tkachuk Y. L., Rudyak O. M., Knyazevych-Chorna T. V.

Ivano-Frankivsk National Medical University, Ministry of Health of Ukraine, Ivano-Frankivsk, Ukraine

zhurakivska.o.ya@gmail.com

One of the complications of diabetes mellitus (DM) is diabetic myopathy, which is diagnosed in $88 \%$ of patients. Therefore, the purpose of our study was to establish the age characteristics of histo-ultrastructural changes in the masticatory muscle of 2 -month (immature) and 6-month (mature) rats with streptozotocin-induced diabetes mellitus (STD). It was induced by a single intraperitoneal injection of streptozotocin $7 \mathrm{mg} / 100 \mathrm{~g}$ body weight in 2 -month animals, and $6 \mathrm{mg} / 100 \mathrm{~g}$ body weight in 6 -month-old rats.

It was found that on the 70th day of STD there was a muscle sequestration and focal aseptic inflammatory cell infiltrates in the masticatory muscle of 2 -month-old rats, while in 6-month-old animals the fibrosis and focal lysis of individual muscle fibers (MF), sometimes their necrosis and partial replacement by connective tissue were noticed. Sonography revealed in 6-month-old rats partial necrosis of MF, karyorexis, subsarcolemic edema, fibrosis and lysis of myofibrils, destruction of mitochondria; 2-month animals had intracellular regenerative processes: formation of young mitochondria, appearance of numerous granules of glycogen in the sarcoplasm between myofibrils. Such changes occur against the background of the diabetic microangiopathy. Adult animals had a massive destruction of neuromuscular junctions (NMJs) and it leads to a decrease in the area of axon sprouting by $67 \%$ and is accompanied by partial destruction of neuromuscular synapses. In 2 -month-old rats, there was also a decrease in the area of NMJs by $54 \%$, while in some NMJs the reinnervation processes were noted due to collaterals from neighboring nerve fibers.

Thus, diabetic myopathy is diagnosed in the masticatory muscle of SDM rats of different ages, which results from the development of diabetic microangiopathy and peripheral neuropathy. In adult animals, it leads to atrophy and partial sclerosis of MF of the masticatory muscle, and in immature animals, compensatory-restorative processes are observed in the NMJs and MF.

Key words: masticatory muscle, neuromuscular junction, streptozotocin-induced diabetes mellitus. 